\title{
Accumulation of cadmium by Palaemon elegans (Crustacea: Decapoda)
}

\author{
S. L. White \& P. S. Rainbow \\ School of Biological Sciences, Queen Mary College, University of London, Mile End Road, London E1 4NS, England
}

\begin{abstract}
Accumulation of cadmium by the shrimp Palaemon elegans has been examined using $\mathrm{Cd}$ 109 as a tracer. Cadmium accumulation by individual shrimp is linear with time unless modified by moulting. Rates of $\mathrm{Cd}$ accumulation vary widely between individuals but the variation could not be attributed to differences in dry weight, sex, nor stage in the moult cycle, suggesting genetic variation, Rate of cadmium accumulation is increased for an indeterminate period after moulting. Loss of cadmium by whole shrimps is also variable and appears unrelated to external Cd concentration. Rates of cadmium accumulation into different tissues of $P$. elegans vary widely, the rate into the hepatopancreas being 100 times that for the muscle. Cast moults take up cadmium from the surrounding medium.
\end{abstract}

\section{INTRODUCTION}

Cadmium is a very toxic metal often associated with and chemically similar to zinc but, unlike zinc, cadmium has no known metabolic role. The ability of many edible marine organisms to accumulate cadmium is potentially hazardous to human health (Joint FAO/WHO Expert Committee on Food Aditives 1972). Such concerns and the possibility of using marine organisms to monitor levels of cadmium in the marine environment (Phillips 1977, 1980a, Bryan et al. 1980) have prompted studies on the kinetics of cadmium uptake and loss in a variety of species (see Coombs 1979, Phillips 1980b)

Some crustaceans, especially the decapods, can regulate body concentrations of certain metabolically essential heavy metals such as copper and zinc (Bryan 1966, White \& Rainbow 1982, 1984a, b, Rainbow 1985), but there is no evidence that they can regulate nonessential metals such as cadmium and mercury (Vernberg et al. 1974, Bengtsson 1977, Wright 1977, Dethlefsen 1978, White \& Rainbow 1982, Rainbow 1985). Different aspects of the kinetics of cadmium uptake and loss have been examined in a range of crustacean species; these include the effects of different dissolved cadmium concentrations (Gillespie et al. 1977, Dethlefsen 1978, Jennings \& Rainbow 1979) and changes in physico-chemical variables such as salinity (Wright 1977) and temperature (Bengtsson 1977). The accumulation of cadmium into different tissues has also been studied (Nimmo et al. 1977, Wright 1977,
Jennings \& Rainbow 1979, Ray et al. 1980) while the loss of cadmium from whole animals has been described in terms of variously sized component models (Benayoun et al. 1974, Fowler \& Benayoun 1974).

The present study examines some aspects of cadmium kinetics in the decapod crustacean Palaemon elegans, a species in which zinc kinetics have recently been investigated (White \& Rainbow 1984a, b).

\section{MATERIALS AND METHODS}

Palaemon elegans Rathke from Millport, Isle of Cumbrae, Firth of Clyde, U. K., were acclimated to the experimental temperatures and artificial seawater medium, Tropic Marin New (TMN, Tropicarium Buchschlag, Dreieich, F. R. Germany) before commencing any experiments. TMN was chosen because it provided a more reproducible medium than laboratory seawater, particularly with respect to levels to trace metals and dissolved organic matter. TMN prepared with fresh distilled water contained $>0.5 \mu \mathrm{g} \mathrm{Cd} \mathrm{l}^{-1}$.

Individual shrimps (or moults) were rinsed briefly in TMN before drying to constant weight at $60^{\circ} \mathrm{C}$ and digesting in conc. nitric acid (Aristar grade, BDH Ltd.) at $100^{\circ} \mathrm{C}$. Digested samples were made up to volume and analysed for total cadmium using a Varian AA-375 series atomic absorption spectrophotometer fitted with a continuous deuterium background correction lamp. Where appropriate, digests were counted for Cd-109 activity in a Nuclear Chicago 1185 gamma scintillation 
counter using known standards of the same sample geometry after correcting for background radiation. Live shrimps were also counted for Cd-109 activity as described by White \& Rainbow (1984a) for Zn-65 in Palaemon elegans.

In all experiments a 12:12 light: dark regime was employed and the salinity was maintained at $33 \%$. Experimental solutions were aerated and covered to prevent evaporation or contamination. TMN was dosed to required metal concentration by addition of $\mathrm{CdCl}_{2}$ incorporating carrier-free Cd-109 (Amersham U.K. Ltd.) as required. Samples of TMN were taken throughout the experiments to monitor for $\mathrm{Cd}-109$ activity. Every other day shrimps were transferred to undosed TMN and allowed to feed for $20 \mathrm{~min}$ on lamb's heart which had a suitably low concentration of cadmium (0.4 $\mu \mathrm{g} \mathrm{g}^{-1}$ dry weight) to have a negligible effect as a dietary source of metal.

\section{Experimental details}

Uptake and loss of $C d$ in whole shrimp: Expt 1. Ten shrimps, held individually in a compartmented Pers-

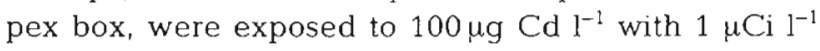
Cd-109 as a tracer in $15 \mathrm{l}$ of TMN for $10 \mathrm{~d}$ without change of experimental medium. On Day 10, shrimps, taken at random, were transferred to 0.81 polythene beakers and exposed separately, in 0.51 of TMN, to

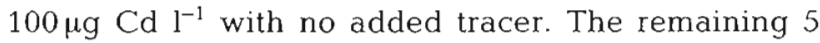
shrimps were transferred separately to $0.5 \mathrm{l}$ of undosed TMN. To minimize recycling of Cd-109, experimental media were changed on Days 12, 14, 16, 20 and every $5 \mathrm{~d}$ subsequently. The experiment was terminated after a total of $50 \mathrm{~d}$. During the initial $10 \mathrm{~d}$ all shrimps were counted for Cd-109 activity on Days 1, 2, 5, 7 and 10 ; subsequently shrimps were counted at varying intervals (see Fig. 4). Temperature was maintained at $10^{\circ} \mathrm{C} \pm 1 \mathrm{C}^{\circ}$.

Expt 2: To further investigate the variation in cadmium uptake between individuals, 12 shrimps held individually in a Perspex box were exposed to $50 \mu \mathrm{g} \mathrm{Cd}$ $\mathrm{l}^{-1}$ with $2 \mu \mathrm{Ci} \mathrm{l}^{-1} \mathrm{Cd}-109$ as a tracer for $10 \mathrm{~d}$ in $15 \mathrm{l}$ of TMN at $15^{\circ} \mathrm{C} \pm 1 \mathrm{C}^{\circ}$. Shrimps were counted for $\mathrm{Cd}$ 109 activity every 2 nd day.

Cadmium uptake into individual tissues: Expt 3. Twenty-four separately held Palaemon elegans were exposed to $100 \mu \mathrm{g} \mathrm{Cd} \mathrm{l}^{-1}$ with $1 \mu \mathrm{Ci} \mathrm{l}^{-1} \mathrm{Cd}-109$ as a tracer in $20 \mathrm{l}$ of $\mathrm{TMN}$ at $10^{\circ} \mathrm{C} \pm 1 \mathrm{C}^{\circ}$ for $20 \mathrm{~d}$. At intervals, 4 shrimps were removed and dissected into cuticle, abdominal muscle ('muscle'), hepatopancreas, gill, eyes (+ eyestalks) and other soft tissues ('rest'). Tissues from individuals were then dried, digested and analysed for Cd-109. Due to the low total cadmium concentrations in some tissue digests it was not possible to complete budgets for total cadmium.

Throughout this paper the term 'labelled cadmium' refers to the cadmium taken up while $\mathrm{Cd}-109$ was added as a tracer.

All metal concentrations are quoted as $\mu \mathrm{g} \mathrm{g}^{-1}$ dry weight. The term accumulation is defined here to be equivalent to net accumulation.

Linear regression analyses were performed as in Sokal \& Rohlf (1969).

\section{RESULTS}

\section{Metal concentrations in experimental media}

In the labelled phases of all experiments the total cadmium concentrations (based on Cd-109 activity) in the TMN varied by less than $3 \%$ from the stated concentrations. It can be assumed that cadmium losses would be equally small during non-labelled phases. There was no detectable Cd-109 activity in TMN samples taken during the non-labelled phase of Expt 1 indicating negligible recycling of labelled cadmium.

\section{Accumulation of labelled cadmium in whole shrimps: Expts 1 and 2}

The accumulation of labelied cadmium by individual shrimps in Expt 1 is linear with time except where modified by moulting (Fig. 1). The rates of cadmium accumulation vary 4 -fold (excluding the postmoult rate for Animal 10), and showed an apparent inverse relation with the size (dry weight) of the shrimps (Fig. 2a). Statistical analysis using Spearman's rank correlation gave a probability of $p=0.06$ that there was no relation between cadmium accumulation rate and shrimp dry weight. As however the observed probability was close to the $p<0.05$ level, another experiment (Expt 2: see Fig. 3) was performed to further test for a relation between cadmium accumulation rate and shrimp size. For these data from Expt 2, a plot of pre-moult rates of cadmium accumulation against dry weight (Fig. 2b) showed an apparent positive relation though this was not significant at the $p<$ 0.05 level ( $p=0.15$, Spearman's rank correlation). As the probabilities from both experiments are not significant at the $p<0.05$ level and the apparent relation in Expt 1 was the converse of that in Expt 2 it is concluded that there is no relation between cadmium accumulation rates and shrimp dry weight.

A feature of the accumulation of labelled cadmium shown in Fig. $1 \& 3$ is the considerable effect of moult- 

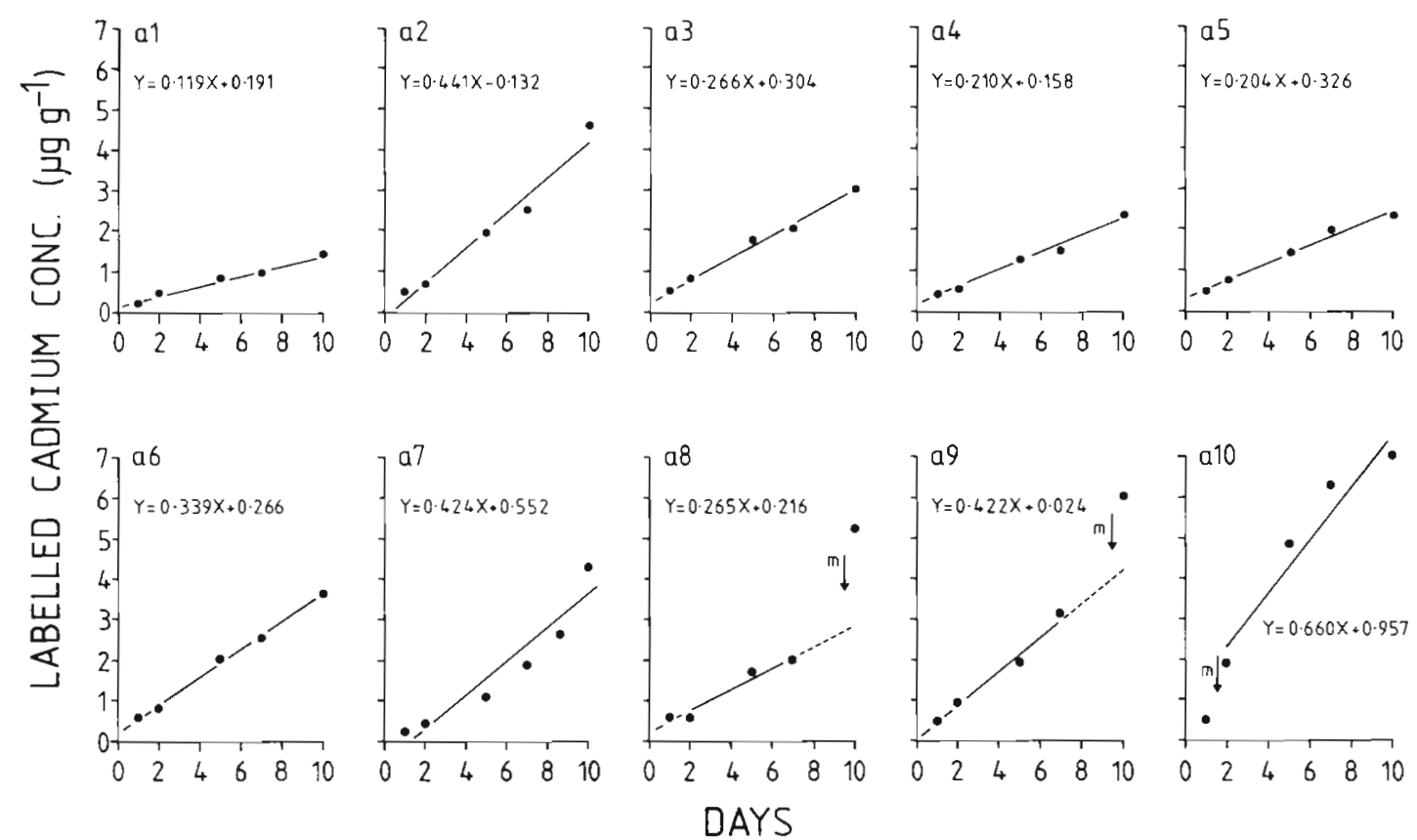

Fig. 1. Palaemon elegans. Accumulation of labelled Cd by 10 individual shrimps (a1 to a10) exposed to $100 \mu \mathrm{g} \mathrm{l^{-1 }}$ labelled Cd for $10 \mathrm{~d}$ at $10^{\circ} \mathrm{C}$ (Expt 1). Calculated regression lines (equations shown) use all data points except for a 8 and a9 (4 points before and after moulting respectively; $p<0.01$ for all specimens, except a10 where $p<0.05$ ). $\mathrm{m}$ : time of moult if present; dashed line: extrapolation of calculated regression line to show predicted concentration of labelled $\mathrm{Cd}$ in the absence of moulting

Fig. 2. Palaemon elegans. Premoult rates of labelled cadmium accumulation plotted against shrimp dry weight for (a) 9 shrimps exposed to $100 \mu \mathrm{g} \mathrm{l}^{-1}$ labelled $\mathrm{Cd}$ for $10 \mathrm{~d}$ at $10^{\circ} \mathrm{C}$ (Expt 1) and (b) 10 shrimps exposed to $50 \mu \mathrm{g} \mathrm{t}^{-1}$ labelled $\mathrm{Cd}$ for $10 \mathrm{~d}$ at $15^{\circ} \mathrm{C}$ (Expt 2). r: rank correlation coefficient; $\mathrm{p}$ : probability that there is no correlation (see text for details)
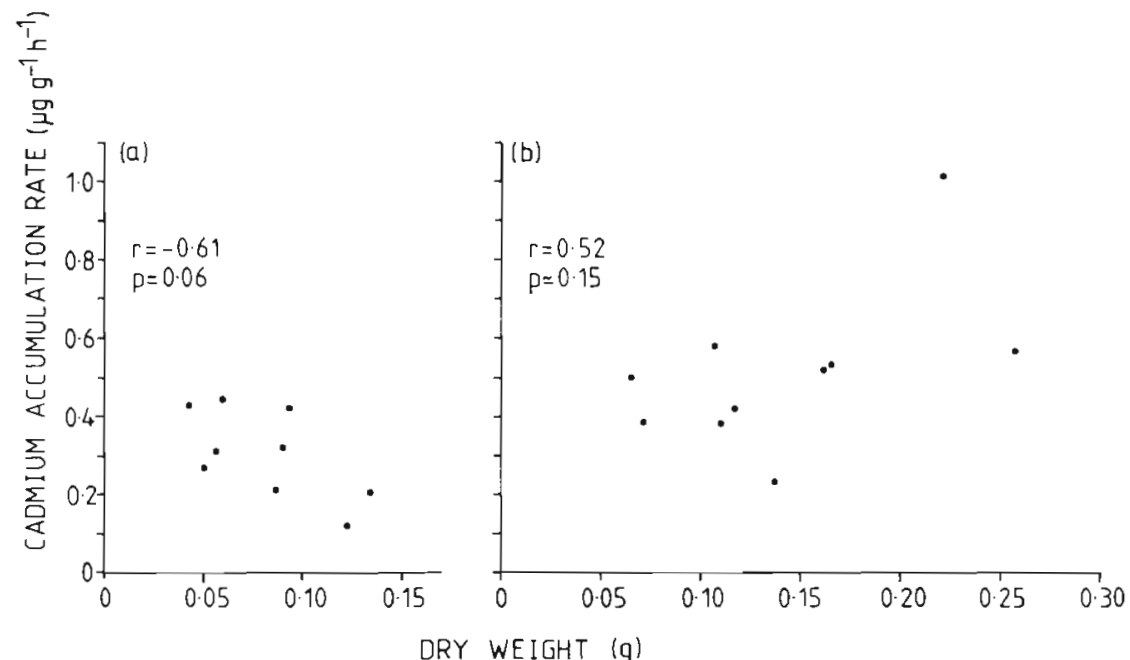

ing. The increases in cadmium concentration on moulting above that predicted by the calculated linear uptake rates range from 0.8 to $7.0 \mu \mathrm{g} \mathrm{Cd} \mathrm{g} \mathrm{g}^{-1}$ though most are approximately $2.0 \mu \mathrm{g} \mathrm{Cd} \mathrm{g}^{-1}$. In addition to the immediate increases in cadmium concentration, the rates of cadmium accumulation are greater after moulting.

In Expt 1 Animal 10 has a post-moult cadmium

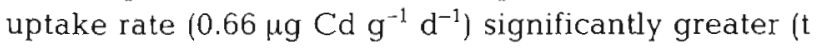

$=2.89, \mathrm{p}=0.02)$ than the mean pre-moult rate $(0.30 \mu \mathrm{g}$ $\mathrm{Cd} \mathrm{g}^{-1} \mathrm{~d}^{-1}$ ) of the other 9 shrimps. Similarly in Expt 2 for all specimens the mean premoult cadmium uptake

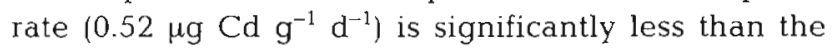
post-moult rate $\left(1.05 \mu \mathrm{g} \mathrm{Cd} \mathrm{g} \mathrm{Cd}^{-1} ; \mathrm{t}=2.94, \mathrm{p}<0.01\right)$. For the 4 shrimps in Expt 2 with measurable rates before $\left(0.47 \mu \mathrm{g} \mathrm{Cd} \mathrm{g}^{-1} \mathrm{~d}^{-1}\right)$ and after $\left(1.30 \mu \mathrm{g} \mathrm{Cd} \mathrm{g}^{-1} \mathrm{~d}^{-1}\right)$ moulting, there is also a significant difference $(t=5.1$, $p<0.01$ ) 

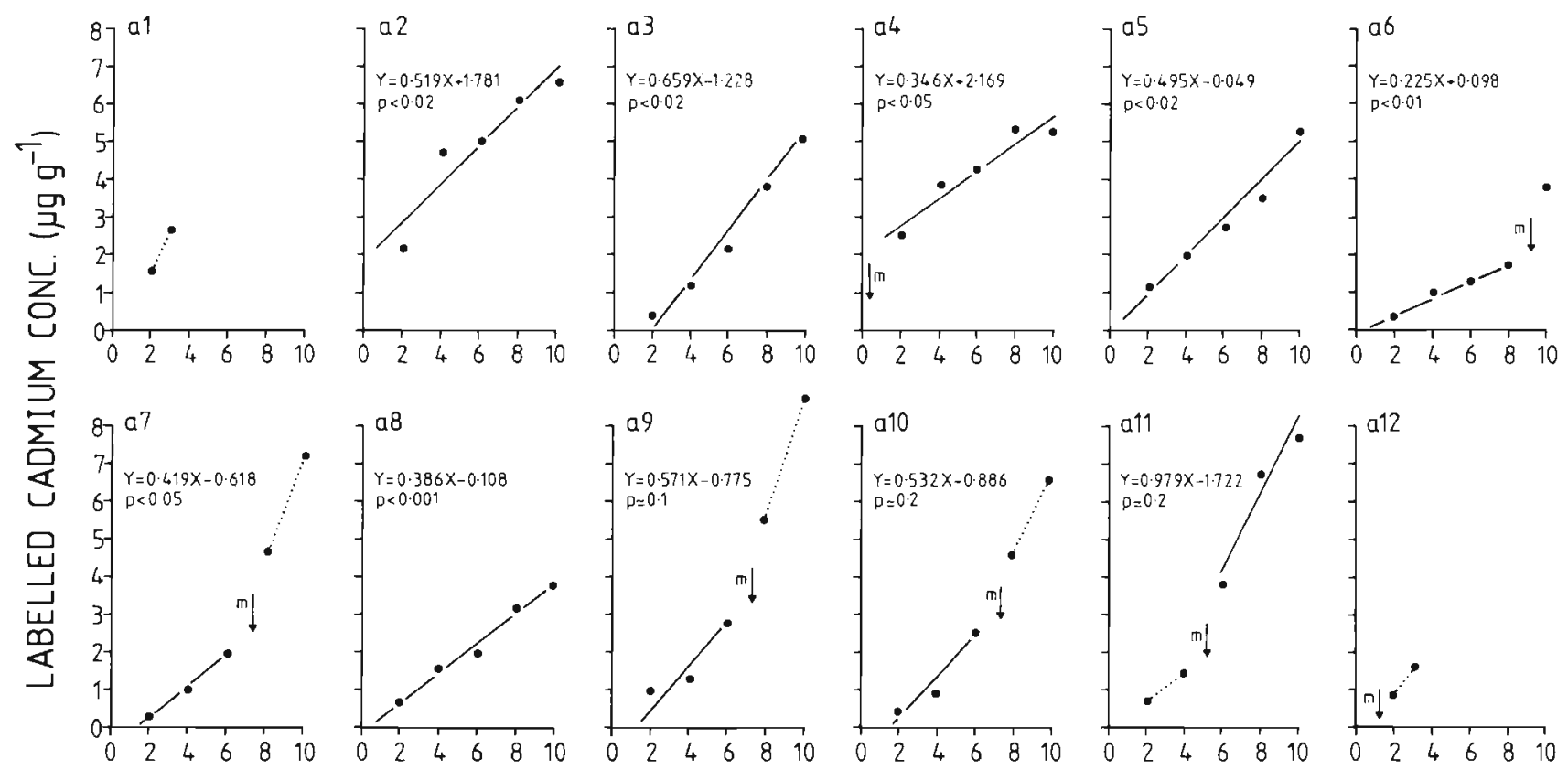

DAYS

Fig. 3. Palaemon elegans. Accumulation of labelled Cd by 12 individual shrimps (al to a12) exposed to $50 \mu \mathrm{g} 1^{-1}$ Iabelled $\mathrm{Cd}$ for $10 \mathrm{~d}$ at $15{ }^{\circ} \mathrm{C}$ (Expt 2). Calculated regression lines (equations shown) use at least 3 data points before or after moulting. Dotted lines join 2 data points. $\mathrm{m}$ : time of moult if present; $\mathrm{p}$ : probability that the slope of the regression line $=0$

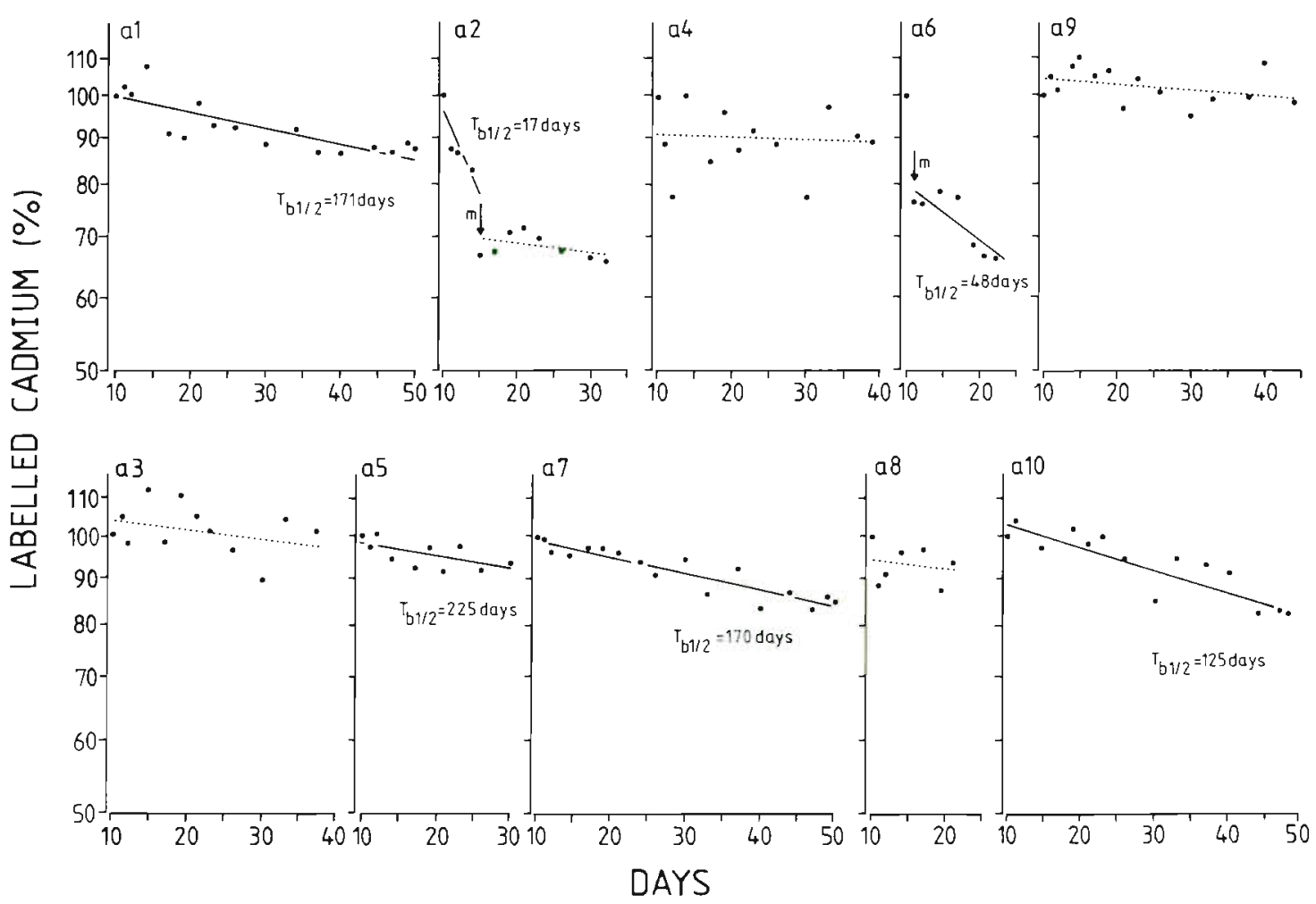

Fig. 4. Palaemon elegans. Loss of labelled $\mathrm{Cd}$ from individual shrimps as percentage of calculated concentration after $10 \mathrm{~d}$ exposure to $100 \mu \mathrm{g} \mathrm{l}^{-1}$ labelled $\mathrm{Cd}$ at $10^{\circ} \mathrm{C}$ (Expt 1): 5 shrimps (a 1, a2, a4, a6, a9) were transferred to $100 \mu \mathrm{g} \mathrm{l}^{-1}$ unlabelled $\mathrm{Cd}$ and $5(\mathrm{a} 3, \mathrm{a} 5, \mathrm{a} 7, \mathrm{a} 8, \mathrm{a} 10)$ to $<0.5 \mu \mathrm{g} \mathrm{l}^{-1}$ unlabelled $\mathrm{Cd}$ for a further $40 \mathrm{~d}$. (N.B. y-axis is a log scale.) m: moult; solid lines: best-fit regression lines significant at $p<0.05$; dashed lines: best-fit regression lines but with slopes not significantly different from 0 ;

$\mathrm{T}_{\mathrm{b}_{1 / 2}}$ : biological half-life of labelled $\mathrm{Cd}$ in the shrimps showing significant Cd loss 


\section{Loss of labelled cadmium: Expt 1}

Losses of labelled cadmium from shrimps expressed as a percentage of the Day 10 concentration are shown in Fig. 4. Six of the 10 shrimps showed significant loss of cadmium which fitted exponential loss curves. The rates of cadmium loss expressed as biological half lives $\left(\mathrm{T}_{\mathrm{b}_{1} / 2}\right)$ appear unrelated to external dissolved cadmium concentrations.

\section{Effect of moulting on cadmium loss}

Two moults occurred during the depuration phase of Expt 1 and these are shown in Fig. 4. Losses of labelled cadmium associated with these moults accounted for 12 and $18 \%$ of the Day 10 total labelled cadmium for Animals 2 and 4 respectively. Analyses of 4 moults for total and labelled $\mathrm{Cd}$ shed during Expt 1 (Table 1) showed that while these moults had similar total $\mathrm{Cd}$ concentrations, the labelled $\mathrm{Cd}$ concentrations were significantly higher in those shed into labelled TMN. This indicates that moults take up large amounts of cadmium after being shed into water with elevated $\mathrm{Cd}$ concentrations.

\section{Total cadmium concentrations in whole shrimps: Expt 1}

Fig. 5 shows the total and labelled $\mathrm{Cd}$ concentrations in shrimps that died during or were sacrificed at the end of Expt 1. There is continued uptake of cadmium by those shrimps continuously exposed to $100 \mu \mathrm{g} \mathrm{Cd} \mathrm{l}^{-1}$ but again, as for labelled cadmium, there are wide differences in uptake rates between individuals. Total cadmium concentrations were not measured in shrimps in Expt 2.

\section{Distribution of total cadmium in unexposed shrimps}

The total cadmium concentrations in individual tissues of unexposed Palaemon elegans expressed as the percentage of the total tissue and soft tissue total are shown in Table 2. While the cuticle has a lower Cd concentration than the shrimp as a whole it bears almost half the body burden by virtue of its relative size. Amongst the soft tissues the gills and eyes have the highest concentrations while the muscle has half the total body cadmium concentration. In terms of the total cadmium content of the soft tissues, however, the muscle, rest and hepatopancreas have approximately equal proportions, the gills and eyes being relatively !ess important.

The calculated total body concentrations given in

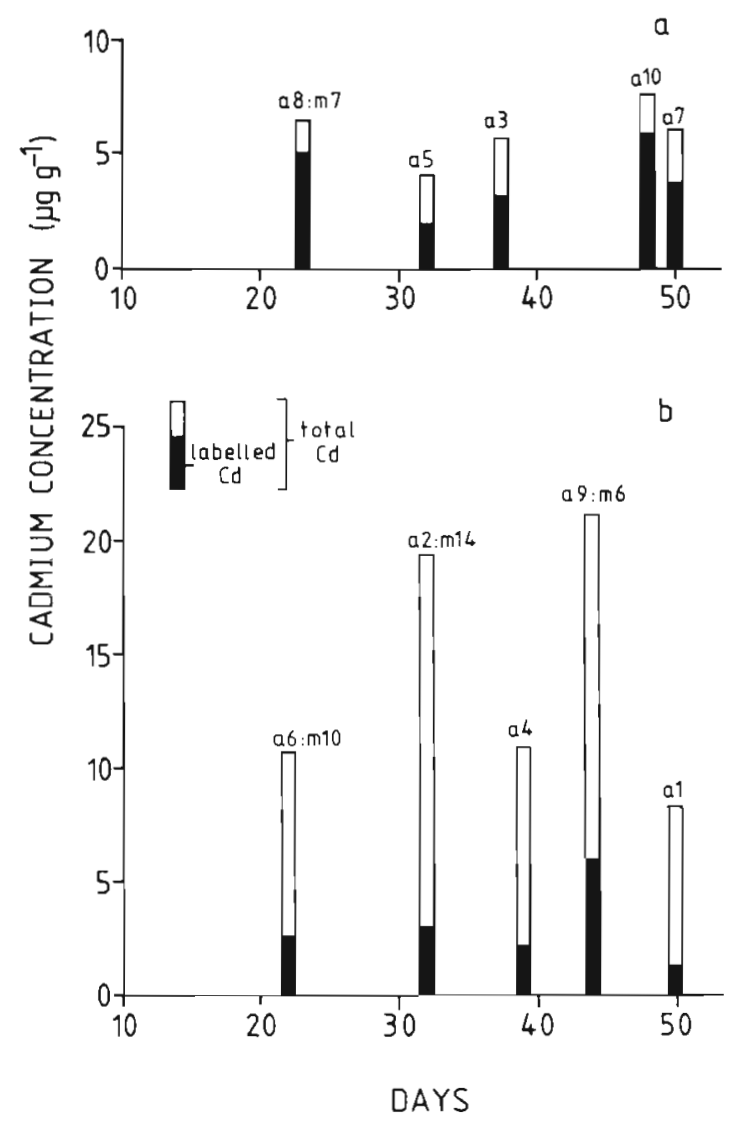

Fig. 5. Palaemon elegans. Concentrations of labelled and total Cd in shrimps exposed to $100 \mu \mathrm{g} \mathrm{l}^{-1}$ of labelled Cd for 10 $\mathrm{d}$ and subsequently either (a) $<0.5 \mu \mathrm{g} \mathrm{l}^{-1}$ or (b) $100 \mu \mathrm{g} \mathrm{l}^{-1}$ of unlabelled cadmium for up to a further $40 \mathrm{~d}$. Sampling points for individual shrimps are at Day 50 or for the points at which individuals died. $\mathrm{m}$ : day of moult if present

Table 1. Palaemon elegans. Cd concentrations $\left(\mu \mathrm{g} \mathrm{g}^{-1}\right)$ in moults (Expt 1)

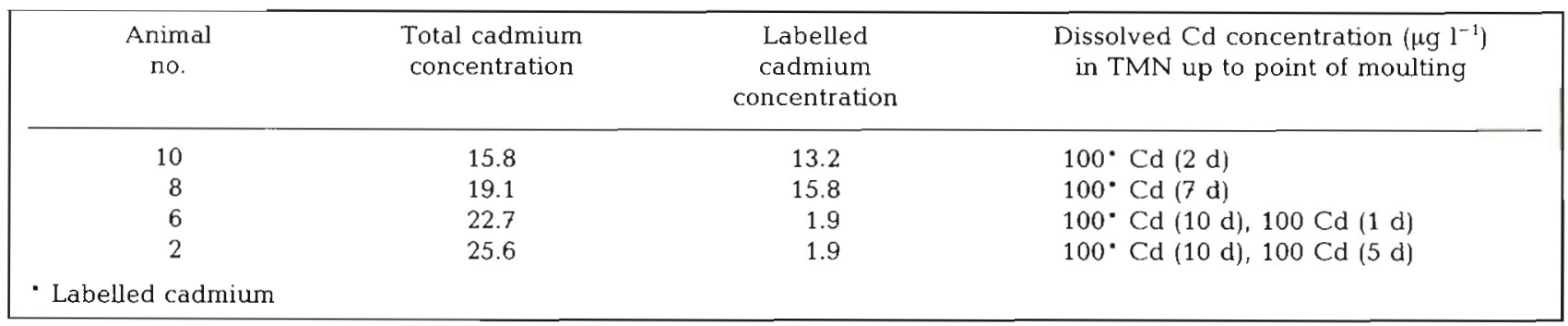


Table 2. Palaemon elegans. Concentrations $\left(\mu \mathrm{g} \mathrm{g}^{-1}\right)$ and percentage body burdens of total cadmium, and percentage dry weight of different pooled tissues of 4 shrimps from Millport. Mean $( \pm \mathrm{SD}, \mathrm{n}=3$ )

\begin{tabular}{|c|c|c|c|c|c|}
\hline Tissue & Cd conc. & $\begin{array}{l}\% \text { of total Cd } \\
\text { body burden }\end{array}$ & $\%$ of $\mathrm{Cd}$ in soft tissues & $\begin{array}{c}\% \text { of total dry } \\
\text { weight }\end{array}$ & $\begin{array}{c}\% \text { of soft tissue } \\
\text { dry weight }\end{array}$ \\
\hline Cuticle & $0.79(0.10)$ & $46.0(4.8)$ & - & $52.2(4.7)$ & - \\
\hline Muscle & $0.45(0.13)$ & $13.9(2.7)$ & $25.7(6.9)$ & $28.0(3.1)$ & $58.6(3.0)$ \\
\hline Hepatopancreas & $1.42(0.23)$ & $12.4(1.4)$ & $22.9(3.2)$ & $8.0(1.9)$ & $16.9(4.6)$ \\
\hline Gill & $4.70(3.15)$ & $6.4(3.9)$ & $11.8(5.0)$ & $1.3(0.1)$ & $2.7(0.3)$ \\
\hline Eye & $3.98(1.38)$ & $5.7(1.7)$ & $10.6(4.1)$ & $1.3(0.1)$ & $2.7(0.3)$ \\
\hline Rest & $1.53(0.06)$ & $15.7(3.8)$ & $29.1(4.4)$ & $9.2(2.6)$ & $19.1(3.6)$ \\
\hline Tissue total & $0.90(0.11)$ & & & & \\
\hline
\end{tabular}

Table 2 can be compared with concentrations in 12 whole, undissected specimens sampled and analysed at the same time. The mean concentration for the

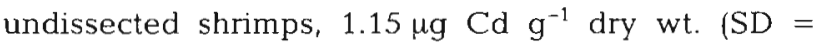
$0.45)$, is not significantly different from that of the tissue total, mean $=0.90 \mu \mathrm{g} \mathrm{g}^{-1}(\mathrm{SD}=0.11)$; $(\mathrm{t}=0.96$, $p \simeq 0.4$ ). It was concluded therefore that the tissue totals produce a valid estimate of the total body cadmium concentrations.

\section{Accumulation of cadmium in individual tissues: Expt 3}

The accumulation of cadmium in the individual tissues of the shrimps varies considerably (Fig. 6), with the hepatopancreas and gill accumulating cadmium at a rate approximately 100 -fold that of the muscle. The pattern of accumulation in each tissue is, initially at least, linear with time though there is some evidence of levelling off between Days 15 and 20. There is however considerable variation in the data and as none of the shrimps moulted this may be explained by the large variation in whole body accumulation rates seen in Expts 1 and 2. It is possible then that by chance the 4 shrimps taken on Day 15 had higher than average cadmium accumulation rates causing the apparent levelling off in cadmium concentrations. Fig. 7 shows the tissue total accumulation of cadmium again demonstrating the wide variation in individual cadmium accumulation rates. Table 3 gives calculated linear uptake rates for the 6 separate tissues and tissue totals. The tissue total accumulation rate of $0.25 \mu \mathrm{g}$

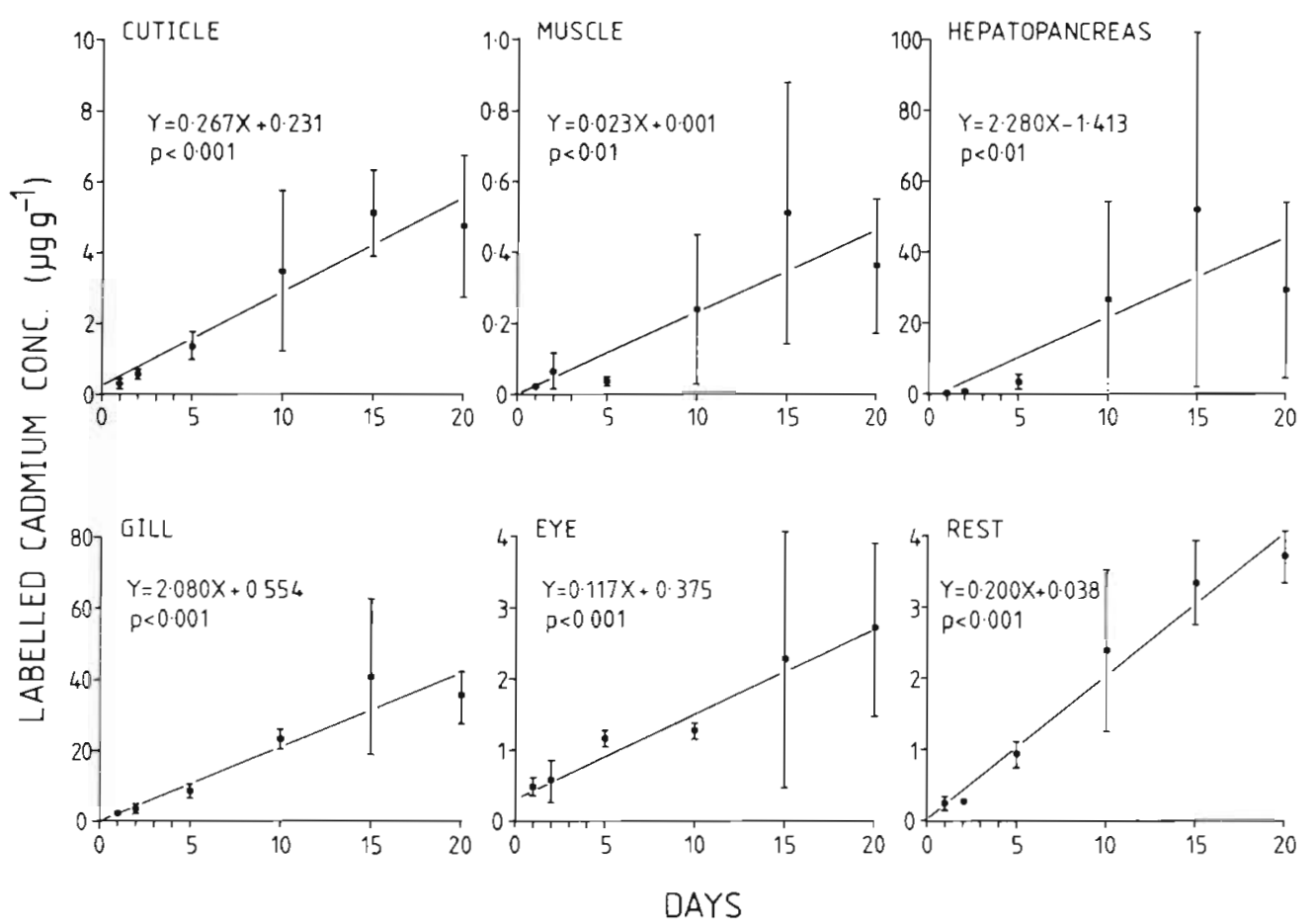

Fig. 6. Palaemon elegans. Concentrations of labelled Cd (means $\pm 1 \mathrm{SD}, \mathrm{n}=4$ ) in tissues of shrimps exposed to $100 \mu \mathrm{g} \mathrm{l}^{-1}$ labelled $\mathrm{Cd}$ at $10^{\circ} \mathrm{C}(\operatorname{Expt} 3)$. Lines drawn are best-fit regression lines. p: probability that the slope of the regression $=0$ 


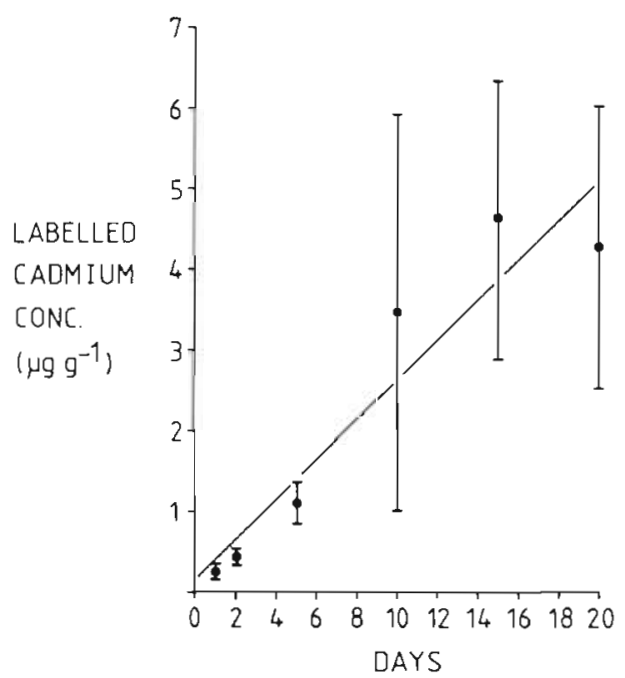

Fig. 7. Palaemon elegans. Labelled cadmium concentrations (mean $\pm 1 \mathrm{SD}, \mathrm{n}=4$ ) in individual shrimps (tissue totals) exposed to $100 \mu \mathrm{g} \mathrm{l^{-1 }}$ of labelled Cd at $10^{\circ} \mathrm{C}$ (Expt 3). Best-fit regression line is $y=0.248 \chi+0.159 ; p<0.01$ )

Table 3. Palaemon elegans. Rates of $\mathrm{Cd}$ accumulation $(\mu \mathrm{g} \mathrm{Cd}$ $\mathrm{g}^{-1} \mathrm{~d}^{-1}$ ) in individual tissues of shrimps exposed to $100 \mu \mathrm{g} \mathrm{Cd}$ $\mathrm{l}^{-1}$ at $10{ }^{\circ} \mathrm{C}($ Expt 3$)$

\begin{tabular}{|lc|}
\hline Tissue & Rate of Cd uptake \\
\hline Cuticle & 0.267 \\
Muscle & 0.023 \\
Hepatopancreas & 2.280 \\
Gill & 2.080 \\
Eye & 0.117 \\
Rest & 0.200 \\
Tissue total & 0.248 \\
\hline
\end{tabular}

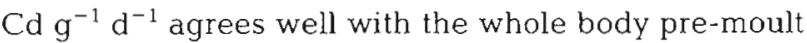
accumulation rate $\left(0.30 \mu \mathrm{g} \mathrm{Cd} \mathrm{g}^{-1} \mathrm{~d}^{-1}\right)$ measured in Expt 1 under identical experimental conditions.

\section{Percentage of total body burden of labelled cadmium in individual tissues}

Fig. 8 shows the percentage of labelled cadmium in each tissue throughout the experiment. In the light of the variability of the cadmium concentration in the cuticle (Fig. 8a), data for other tissues are the proportional amounts in the soft tissues (Fig. 8b).

The proportion of cadmium taken up by the cuticle is, initially, markedly greater than the total unexposed body burden (see Table 2), indicating surface adsorption. Subsequently the proportion in the cuticle decreases as internal tissues accumulate cadmium. Amongst the soft tissues the rapid net accumulation into the hepatopancreas (Fig. 6) is coincident with a marked increase in the proportional body burden,
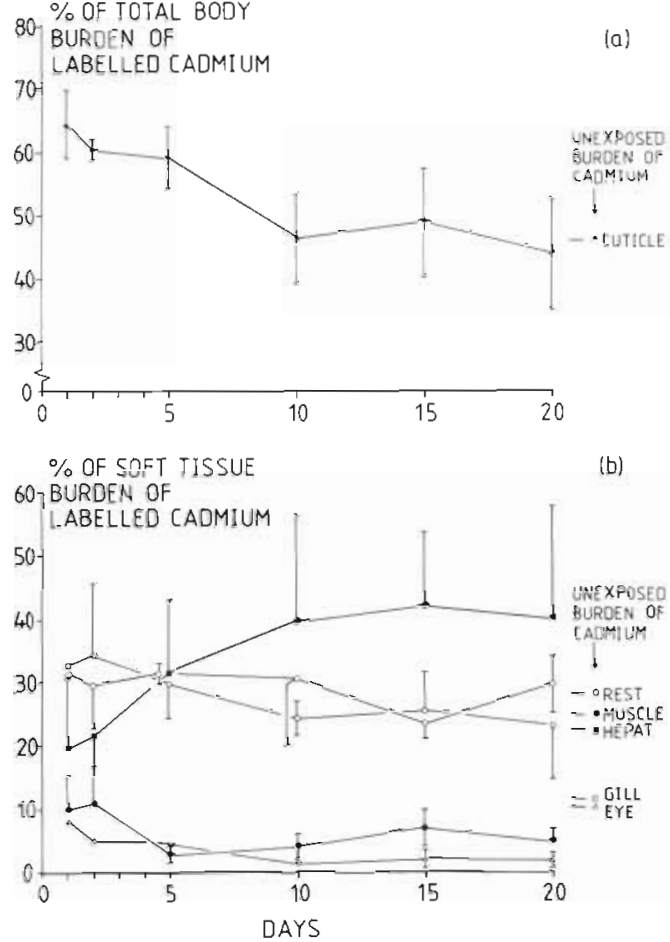

Fig. 8. Palaemon elegans. Distribution of labelled Cd among individual tissues of shrimps exposed to $100 \mu \mathrm{g} \mathrm{l}^{-1}$ labelled $\mathrm{Cd}$ for $20 \mathrm{~d}$ at $10^{\circ} \mathrm{C}$. (a) Percentage of total body burden in the cuticle; (b) percentage of soft tissue body burden. Data are means with only representative standard deviations shown $(n=4)$ for clarity. Percentage distribution of total body cadmium between tissues in unexposed shrimps (Table 2) is shown for comparison

reaching twice the unexposed body burden by Day 20 . All the other tissues show a corresponding decrease in their proportional body burden.

\section{DISCUSSION}

In all 3 experiments described there was considerable variation in cadmium accumulation rates of individual shrimps. This variation, up to 5 -fold, could not be attributed to the sex nor size of the shrimp and hence to variables that may be correlated such as age, metabolic rate or surface area. This wide individual variation in cadmium accumulation rates is similar to the variability in zinc flux found in Palaemon elegans (White \& Rainbow 1984a, b) which similarly could not be explained by differences in size nor sex. The variability in cadmium (and zinc) uptake rates may therefore represent genetic variation which may be expressed in variability in the physiology of trace metal uptake at the cellular level which is still only poorly understood.

Although variation in cadmium uptake rates by Crangon crangon was noted by Dethlefsen (1978), this 
was attributed solely to differences in time between moulting and the beginning of cadmium exposure. In the freshwater crayfish Cambarus latimanus there were no clear relations between cadmium accumulation rates and either sex or size differences (Thorp et al. 1979).

In field analyses of cadmium in crustaceans (e. $\mathrm{g}$. Skwarzec et al. 1984) cadmium concentrations are often inversely related to size. This however does not necessarily indicate faster accumulation rates in small animals, an alternative explanation being that growth rates exceed cadmium uptake rates.

The accumulation of cadmium is increased on moulting and is enhanced for an indeterminate period afterwards. This is similar to increased zinc flux on moulting in Palaemon elegans (White \& Rainbow 1984a, b) and may be due to the increased permeability of the soft cuticle. Changes in cuticle permeability after moulting were considered to account for variability in cadmium uptake rates in Crangon crangon (Dethlefsen 1978), but while this may account for some of the variability seen in $P$. elegans, there is still considerable variation between individuals known to be at the same stage in the moult cycle, i. e. just before and after moulting (see Fig. 1 \& 2).

The rate of cadmium accumulation in Palaemon elegans has been shown to increase with the cadmium concentration in the external medium (White \& Rainbow 1982). Despite this, the mean premoult cadmium accumulation rate in Expt 1 (at $100 \mu \mathrm{g} \mathrm{Cd} \mathrm{l}^{-1}$ ), $0.30 \mu \mathrm{g}$ $\mathrm{Cd} \mathrm{g}^{-1} \mathrm{~d}^{-1}$, was significantly less than that rate in Expt

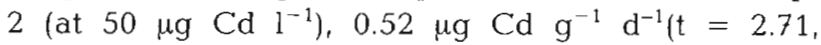
$p<0.02$ ). This may be explained by differences in experimental temperatures, 10 and $15^{\circ} \mathrm{C}$ respectively in Expts 1 and 2. Correcting for differences in cadmium concentrations used (see White \& Rainbow 1982) the rates of cadmium accumulation at $50 \mu \mathrm{g} \mathrm{Cd}^{-1}$ are 0.19 and $0.52 \mu \mathrm{g} \mathrm{Cd} \mathrm{g}^{-1} \mathrm{~d}^{-1}$ at 10 and $15^{\circ} \mathrm{C}$ respectively. By comparison Bengtsson (1977) found a doubling in the cadmium accumulation rate in Leander (= Palaemon) adspersus with a temperature rise from 6 to $15^{\circ} \mathrm{C}$, while in Lysmata seticaudata cadmium accumulation rates increased 4 -fold from 8 to $22^{\circ} \mathrm{C}$ (Fowler \& Benayoun 1974). In $L$. seticaudata however the temperature rise also increased the moulting frequency and it is difficult therefore to identify a separate temperature effect.

Rates of cadmium loss by individual Palaemon elegans show considerable variation with some shrimp losing $\sim 50 \%$ of the previously accumulated total while others showed no significant loss of cadmium in $40 \mathrm{~d}$. Whether some shrimps lose no cadmium at all or whether the rate is too slow to be detectable is not clear though the latter is intuitively more acceptable. The mechanisms of cadmium loss, other than by moulting, have not been investigated but it appears that loss of adsorbed metal is not significant as all shrimps would be expected to show losses of similar magnitude and rate. This is further supported by the fact that cadmium loss was independent of the external cadmium concentration. The implication is that at least some shrimps excrete cadmium and the observed variability in rates of loss may be due to intermittent excretion as found in urinary cadmium excretion in Carcinus maenas (Wright 1977).

A number of studies have examined the loss of cadmium by crustaceans with variable results. Nimmo et al. (1977) found a $50 \%$ loss of cadmium from Penaeus deodarum in 7 to $10 \mathrm{~d}$. Wright (1977) found the same loss from Carcinus maenas in $11 \mathrm{~d}$ and most of this was from the gills and exoskeleton. In contrast Fowler \& Benayoun (1974) found that after 8 mo Lysmata seticaudata still retained $55 \%$ of the cadmium previously accumulated, calculating a biological half life of $307 \mathrm{~d}$ at $13^{\circ} \mathrm{C}$. Such slow rates of loss may explain the observations of other studies (e. g. Dethlefsen 1978, Jennings \& Rainbow 1979, Ray et al. 1980) which report that although small initial losses of cadmium occurred, these were probably attributable to the loss of surface-adsorbed metal and any further loss of cadmium was too slow to be detectable.

The first moult by Palaemon elegans after cadmium exposure accounted for the loss of approximately $15 \%$ of the accumulated cadmium, slightly more than the $10 \%$ loss observed in Megancytiphanes norvegica (Benayoun et al. 1974) and Lysmata seticaudata (Fowler \& Benayoun 1974). The cuticle of Palaemon elegans however contains at least $50 \%$ of the total accumulated cadmium (see Fig. 8) indicating that a large amount of cadmium is absorbed into internal tissues prior to ecydysis.

The rate of labelled cadmium uptake into different tissues varies widely, as much as 100 -fold between the hepatopancreas and muscle. After $20 \mathrm{~d}$ exposure to 100 $\mu \mathrm{g} \mathrm{Cd} \mathrm{l}^{-1}$ the hepatopancreas contained 15 times more cadmium than its proportional body weight suggesting that it has at least a short term detoxification and/or storage function. The presence of cadmium-binding components in the hepatopancreas of $P$. elegans which may be involved in such detoxification mechanisms has been reported elsewhere (White \& Rainbow 1986).

The accumulation of cadmium into different tissues

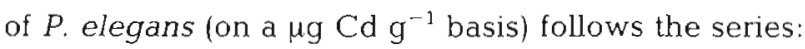

hepatopancreas $>$ gill $>$ cuticle $>$ rest $>$ eye $>$ muscle

and is largely in agreement with similar data for other decapod crustaceans (Eisler et al. 1972, Nimmo et al. 1977, Jennings \& Rainbow 1979, Ray et al. 1980). In most of these studies the absence of data on proportional body weights makes it impossible to calculate 
the proportional cadmium distribution. In 2 studies, however, on Meganyctiphanes norvegicus (Benayoun et al. 1974) and Lysmata seticaudata (Fowler \& Benayoun 1974) the proportional distributions of accumulated cadmium differ markedly from that in $P$. elegans. In both species the cuticle and muscle account for approximately 22 and $50 \%$ of the accumulated cadmium compared with 44 and $2.5 \%$ in Palaemon elegans. While some of this may be explained by the differences in the proportional body weights $(20$ and $50 \%$ for the cuticle and muscle for both species compared with 48 and $33 \%$ in $P$. elegans) there appears to be considerable inter-species variation in the pattern of cadmium accumulation, particularly in the importance of the muscle in the storage of cadmium.

\section{LITERATURE CITED}

Benayoun, G., Fowler, S. W., Oregioni, B. (1974). Flux of cadmium through euphausids. Mar. Biol. 27: 205-212

Bengtsson, B. A. (1977). Accumulation of cadmium in some aquatic animals from the Baltic Sea. In: Aherblom, A. (ed.) 3rd Soviet-Swedish Symposium on the pollution of the Baltic, Rosemon, Sweden 1975. Royal Swedish Academy of Sciences, Ambio Special Reports No. 5

Bryan, G. W (1966). The metabolism of $\mathrm{Zn}$ and ${ }^{65} \mathrm{Zn}$ in crabs, lobsters and freshwater crayfish. In: Aberg, B., Hungate, F. P. (ed.) Radioecological concentration processes. Proceedings of an international symposium, Stockholm. Pergamon Press, New York, p. 1005-1016

Bryan, G. W., Langston, W. J., Hummerstone, L. G. (1980). The use of biological indicators of heavy metal contamination in estuaries. Mar. Biol. Assoc. U.K. Occas. publ. No. 1

Coombs, T. L. (1979). Cadmium in aquatic organisms. In: Webb, M. (ed.) The chemistry, biochemistry and biology of cadmium. Elsevier, Holland, p. 93-139

Dethlefsen, V. (1978). Uptake retention and loss of cadmium by brown shrimp (Crangon crangon). Meeresforschung 26: $137-152$

Eisler, R., Zaroogian, G. E., Hennekey, R. J. (1972). Cadmium uptake by marine organisms. J. Fish. Res. Bd Can. 29: $1367-1369$

Fowler, S. W., Benayoun, G. (1974). Experimental studies on cadmium flux through marine biota. In: Anon. (ed.) Comparative studies of food and environmental contamination. International Atomic Energy Agency, Vienna, p. 159-178

Gillespie, R., Reisine, T., Massaro, E. J. (1977). Cadmium uptake by the crayfish Orconectes propinquus propinquus (Girard). Environ. Res. 13: 364-368

Jennings, J. R., Rainbow, P. S. (1979). Studies on the uptake of cadmium by the crab Carcinus maenas in the laboratory. I. Accumulation from seawater and a food source. Mar. Biol. 50: $131-139$

Joint Food and Agriculture Organization/World Health Organization Expert Comittee on Food Additives (1972).
Sixteenth Report: Evaluation of certain additives and the contaminants mercury, lead and cadmium. FAO Nutrition Meetings Rep. Series 51, WHO Tech. Rep. Series 505

Nimmo, D. W. R., Lightner, D. V., Bahner, L. H. (1977). Effects of cadmium on shrimps Penaeus duodarum, Palaemonetes pugio and Palaemonetes vulgaris. In: Vernberg. F. J. Calabresse, A., Thurberg, F. P., Vernberg, W. B. (ed.) Physiological responses of marine biota to pollutants. Academic press, New York, p. 131-184

Phillips, D. J. H. (1977). The use of biological indicator organisms to monitor trace metal pollution in marine and estuarine environments - a review. Environ. Pollut. 13: $281-317$

Phillips, D. J. H. (1980a). Quantitative aquatic biological indicators. Their use to monitor trace metal and organochlorine pollution. Applied Science Publishers, London

Phillips, D. J. H. (1980b). Toxicity and accumulation of cadmium in marine and estuarine biota. In: Nriagu, J. O. (ed.) Cadmium in the environment, Pt. 1: Ecological cycling. John Wiley and Sons, New York, p. 425-569

Rainbow, P. S. (1985). Accumulation of $\mathrm{Zn}, \mathrm{Cu}$ and $\mathrm{Cd}$ by crabs and barnacles. Estuar. coast. Shelf Sci. 21: 669-686

Ray, S., McLeese, D. W., Wainwood, B. A., Pezzack, D. (1980). The disposition of cadmium and zinc in Pandalus montaqui. Archs environ. Contam. Toxicol. 9: 675-681

Skwarzec, B., Kentzer-Baczeiska, A., Styczynska-Jurewicz, E., Neugebauer, E. (1984). Influence of accumulation of cadmium on the content of other microelements of two species of Black Sea decapods. Bull. environ. Contam. Toxicol. 32: 93-101

Sokal, R. R., Rohlf, F. J. (1969). Biometry. Freeman and Co., San Francisco

Thorp, J. H., Giesy, J. P., Wineriter, S. A. (1979). Effects of chronic cadmium exposure on crayfish, survival, growth and tolerance to elevated temperatures. Archs environ. Contam. Toxicol. 8: 449-456

Vernberg, W. B., DeCoursey, P. J., O'Hara, J. (1974). Multiple environmental factor effects on physiology and behaviour of the fiddler crab Uca pugilator. In: Vernberg, F. J., Vernberg, W. B. (ed.) Pollution and physiology of marine organisms. Academic Press, New York, p. 381-425

White, S. L., Rainbow, P. S. (1982). Regulation and accumulation of copper, zinc and cadmium by the shrimp Palaemon elegans. Mar. Ecol. Prog. Ser. 8: 95-101

White, S. L., Rainbow, P. S. (1984a). Regulation of zinc concentration by Palaemon elegans (Crustacea:Decapoda): zinc flux and effects of temperature, zinc concentration and moulting. Mar. Ecol. Prog. Ser. 16: 135-147

White, S. L., Rainbow, P. S. (1984b). Zinc flux in Palaemon elegans (Crustacea:Decapoda): moulting, individual variation and tissue distribution. Mar. Ecol. Prog. Ser. 19: 153-166

White, S. L., Rainbow, P. S. (1986). A preliminary study of Cu-, $\mathrm{Cd}$ - and $\mathrm{Zn}$-binding components in the hepatopancreas of Palaemon elegans (Crustacea:Decapoda). Comp. Biochem. Physiol. 83C: 111-116

Wright, D. A. (1977). The effect of salinity on cadmium uptake by the tissues of the shore crab Carcinus maenas (L.). J. exp. Biol. 67: p. 137-146 